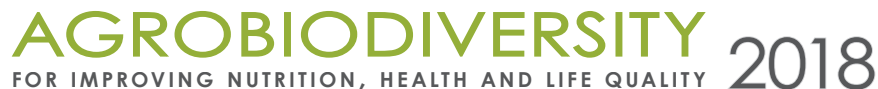

(3)

\section{TOTAL ANTIOXIDANT CAPACITY IN THE MUSCLE TISSUE OF RAINBOW TROUT (ONCORHYNCHUS MYKISS WALBAUM) UNDER IN VITRO INCUBATION WITH LEAF EXTRACTS OF SOME THYMUS (LAMIACEAE) REPRESENTATIVES}

\author{
Honcharenko Vitaliy ${ }^{1}$, Tkachenko Halyna*2, Nachychko Viktor ${ }^{1,3}$, \\ Prokopiv Andriy ${ }^{1,3}$, Osadowski Zbigniew ${ }^{2}$ \\ ${ }^{1}$ Department of Botany, Faculty of Biology, Ivan Franko National University of Lviv, Lviv, Ukraine \\ ${ }^{2}$ Institute of Biology and Environmental Protection, Pomeranian University in Słupsk, Poland \\ ${ }^{3}$ Botanic Garden of Ivan Franko National University of Lviv, Lviv, Ukraine
}

Received: 11. 10. $2018 \quad$ Revised: 28. 10.2018 Published: 10. 12. 2018

The aim of this study was to evaluate the in vitro effect of buffer extracts obtained from leaves of various representatives of Thymus genus on the total antioxidant capacity (TAC) of the muscle tissue of the rainbow trout (Oncorhynchus mykiss Walbaum). Leaves of Thymus serpyllum L. emend. Mill., Th. pannonicus All., Th. pulegioides L., Th. $\times$ porcii Borbás (a hybrid between Th. pannonicus and Th. pulegioides), Th. alpestris Tausch ex A. Kern. were harvested to study. Freshly collected leaves were washed, weighted, crushed, and homogenized in $0.1 \mathrm{M}$ phosphate buffer (pH 7.4) (in proportion $1: 19$, $\mathrm{w} / \mathrm{w}$ ) at ambient temperature. The supernatant of the rainbow trout muscle tissue was used to incubate with leaf extracts of various representatives from Thymus genus (in a ratio 19:1) at room temperature. The most potent antioxidant effect was demonstrated for the extracts of Th. alpestris, Th. $\times$ porcii, Th. pannonicus, Th. serpyllum, and Th. pulegioides compared to phosphate buffer control $(59.5,48$, $45.9,43.9$, and $38.8 \%, p<0.05$, respectively). The results of this study provide a new perspective on the use of various Thymus species as a medicinal plant to improve the antioxidant response of rainbow trout. Further studies including the use of other medicinal plants as food additives in aquaculture, the assessment of its antioxidant effects on various tissues are in progress.

Keywords: Thymus, leaf extracts, rainbow trout (Oncorhynchus mykiss Walbaum), muscle tissue, total antioxidant capacity

\section{Introduction}

Recently, medicinal plants came as a promising and substitute method for the control of fish disease in aquaculture that offers an alternative because of their immunomodulatory effects, to the drugs, chemicals, and antibiotics currently used in aquaculture to control diseases (Galina et al., 2009). Additionally, medicinal plants are used in aquaculture not only as

\footnotetext{
*Corresponding author: Halyna Tkachenko, Institute of Biology and Environmental Protection, Pomeranian University in Słupsk, Arciszewski Str. 22b, 76-200 Słupsk, Poland; $\triangle$ tkachenko@apsl.edu.pl
} 
chemotherapeutics but also as feed additives, as they contain a wide variety of nutrients and chemical compounds with many biological activities including growth promotion, appetite stimulation, immune stimulation, antimicrobial, and anti-stress in fish (Chang, 2000; Galina et al., 2009; Citarasu, 2010). The mechanisms of action of plants and their derivatives are attributed to the presence of many active second metabolites such as alkaloids, steroids, phenolics, tannins, terpenoids, saponins, glycosides, and flavonoids (Galina et al., 2009; Citarasu, 2010; Harikrishnan et al., 2011). Therefore, the development of new additives for aquaculture still attracts the attention of many researchers and fish farmers comprising the eco-friendly approach for the control of fish pathogens.

Plants of the mint family (Lamiaceae) produce many metabolites with antioxidant properties, that are present as secondary metabolites which are synthesized as a defence mechanism. Particularly, Thymus spp. also produce secondary metabolites with antimicrobial, antioxidant, antimicrobials, expectorants, antitussives, and antiplatelet drugs (Kulevanova et al., 2000; Figueiredo et al., 2008; Costa et al., 2012). The genus Thymus L. consists approximately 215 species currently recognized (Morales, 2002). These herbaceous perennials and subshrubs distributed in Europe, Northwest Africa, Ethiopia, Asia and Greenland (Morales, 2002; Bartolucci et al., 2013). It is one of the most widely used genera in folk medicine, where it is popular for its stimulatory action on all organism functions (Viuda-Martos et al., 2011). Many species of this genus are used in traditional medicine as tonics, carminatives, antitussives, aromatic, expectorant, stomachic, antispasmodic, bronchospasmolytic, diuretic, sedative, diaphoretic, and antiseptics, as well as anti-inflammatory, antioxidant, anthelmintic, hepatoprotective and antitumor agents (Khan and Abourashed, 2010; Nabavi et al., 2015). Internally, thyme is used for treatment of acute bronchitis, laryngitis, whooping cough, chronic gastritis, diarrhea, and lack of appetite, while externally in baths to treat rheumatic and skin problems (bruises, sprains, fungal infections) as well as for minor arthritis, gum disease, tonsillitis, etc. (Khan and Abourashed, 2010). Moreover, Thymus species have wide application nowadays in food as a culinary herb and food flavoring, as well as in cosmetics and pharmaceutics in toothpaste, soaps, detergents, creams, lotions, and perfumes. Thymus i.e. leaves of Th. vulgaris L. and Th. zygis L. is used as a spice in several foods.

With the increasing interest in herbal medicine, environmental protection, and natural products, numerous research in herbal or natural product studies has been published in recent years (Kuklina et al., 2017; Vergun et al., 2017). However, literature data on the antioxidant activity of Thymus species in the aquacultural application is practically unknown.

In the last decades, more attention is received the plants possessed antioxidative properties as important inputs in organic fish farming. Sönmez et al. (2015) have evaluated effects of dietary supplementation of sage (Salvia officinalis), mint (Mentha spicata) and thyme (Thymus vulgaris) oils on growth performance, lipid peroxidation level (malondialdehyde, MDA) and liver antioxidant enzyme activities (superoxide dismutase, SOD; catalase, CAT; glucose-6-phosphate dehydrogenase, G6PD; glutathione reductase, GR; glutathione-Stransferase, GST and glutathione peroxidase, GPx) in rainbow trout juveniles. Their work demonstrated changes in oxidative stress indices and antioxidant defense systems in the liver of rainbow trout after long-term exposure to different plant oils. Sage and thyme oils 
have been determined as convenient and useful antioxidant enzyme stimulators and growth promoters. Although, mint oil generally caused an increase in almost all antioxidant enzyme levels, all growth parameters, feed conversion ratio, and survival were negatively affected by mint diets. Therefore, it is suggested that mint has some undesirable effects on rainbow trout physiology and is not a suitable feed additive. Overall, dietary inclusion of sage and thyme oils is effective in enhancing rainbow trout growth, reduction in MDA and least changing antioxidant enzyme activities at a low level of $500 \mathrm{mg}$ per kg diet, and they can be used as important feed supplements for rainbow trout production (Sönmez et al., 2015). To evaluate the effect of different antioxidant and antimicrobial sources, semi-fried mullet fish fillets were dipped into an edible coating solution containing thyme and marjoram at 2.5 and $5.0 \%$ and stored at $4{ }^{\circ} \mathrm{C}$. Samples coated with $5 \%$ thyme showed the lowest rate of peroxide formation (Yasin and AbouTaleb, 2007). Moreover, coated samples with thyme at 2.5 or $5 \%$ showed the lowest incremental pattern in psychrophilic bacterial counts at any point of time during the cold storage (Kostaki et al., 2009). Therefore, these results indicate the potential use of these plant oils.

Therefore, the objective of the present study was to evaluate the in vitro the effect of buffer extracts obtained from leaves of various representatives from Thymus genus on the total antioxidant capacity (TAC) in the muscle tissue of the rainbow trout (Oncorhynchus mykiss Walbaum). TAC is an indicator frequently used to assess the antioxidant status of biological samples and can evaluate the antioxidant response against the free radicals produced in a given disease (Rubio et al., 2016).

\section{Materiall and methodology}

\section{Collection of plant materials}

Samples were harvested in June-August, 2016. Leaves of Thymus serpyllum L. emend. Mill. were collected among grass on sandy soil in the edge of a pine forest (Baymaky village, Bilohirya

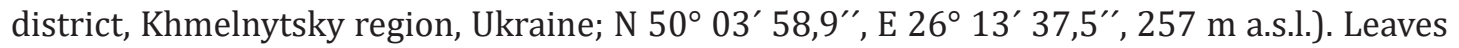
of Th. pannonicus All. were harvested among grass in the roadside between the two cultivated fields (Syvky village, Bilohirya district, Khmelnytsky region, Ukraine; N 50 02' 09.6", E $26^{\circ} 13^{\prime} 19.2^{\prime \prime}, 283 \mathrm{~m}$ a.s.l.). Leaves of Th. pulegioides L. were collected among grass nearby land parcels (Syvky village, Bilohirya district, Khmelnytsky region, Ukraine; N 50 02' 02.8", E $26^{\circ} 14^{\prime} 13.9^{\prime \prime}, 306 \mathrm{~m}$ a.s.l.). Leaves of Th.× porcii Borbás (a hybrid between Th. pannonicus and Th. pulegioides) were sampled in the grass stand, on the side of the footpath of the race track (Medovoi Pechery Str., Lviv, Ukraine; N 49 49`15.1“, E 24 05‘ 12.5“' 348 m a.s.l.). Leaves of Th. alpestris Tausch ex A. Kern. were harvested on the side of the road below the stream, in mountain valley Shumneska (Kvasy village, Rakhiv district, Zakarpattia region, Ukraine; $\mathrm{N} 48^{\circ}$ 09'32.3“, E 24 21'26.4“, 1259 m a.s.l.) (Figure 1).

Identification of these five taxa was made according to Nachychko $(2014,2015)$ and Nachychko and Honcharenko (2016). The voucher herbarium specimens of plants used in this study were deposited at the Herbarium of M.G. Kholodny Institute of Botany of the National Academy of Sciences of Ukraine (KW). Plant samples were thoroughly washed to remove all attached material and used to prepare extracts. 
Honcharenko, V., Tkachenko, H., Nachychko, V., Prokopiv, A., Osadowski, Z.

Agr.bio.div. Impr. Nut., Health Life Qual., 2018, 223-233
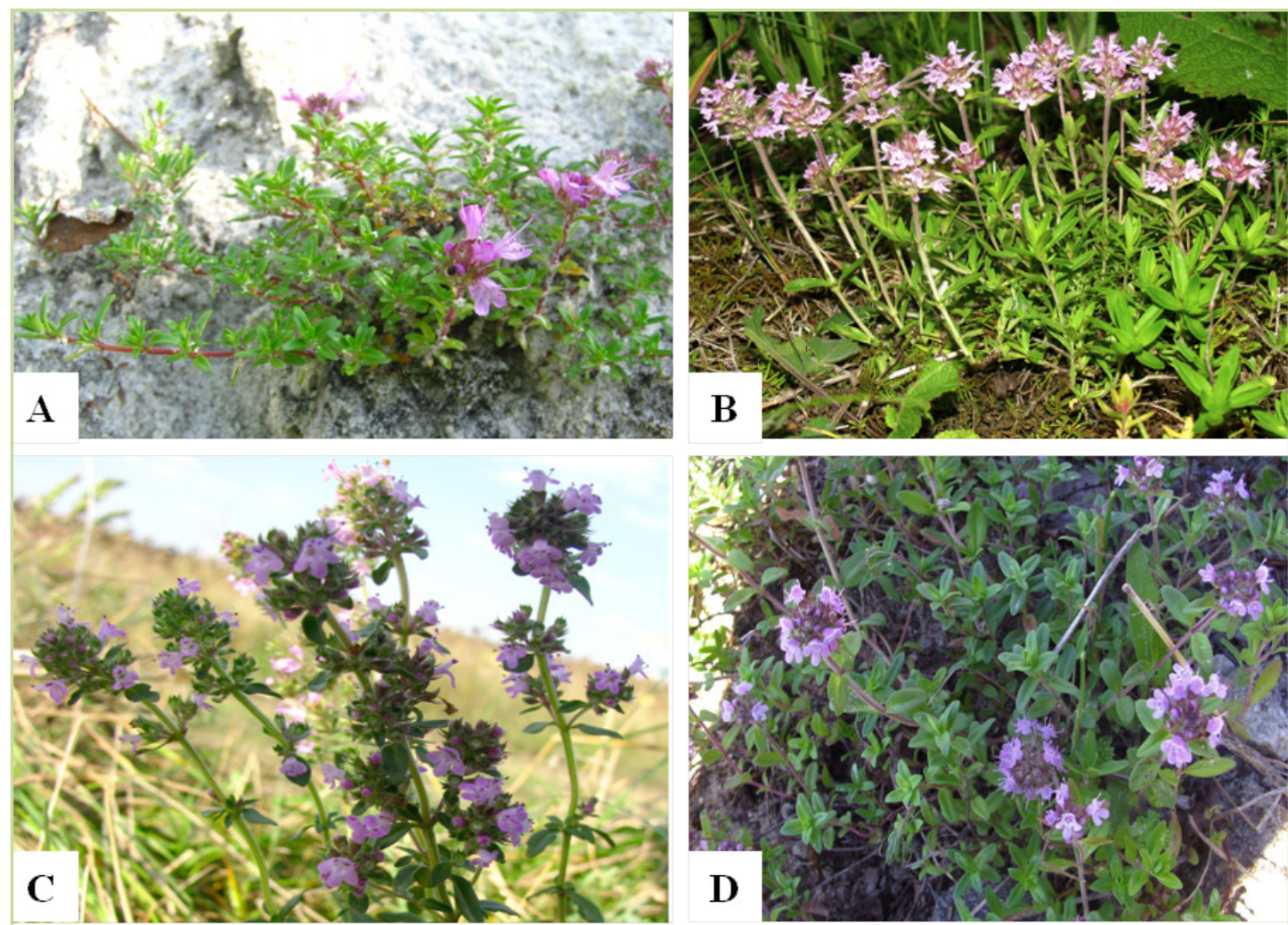

D

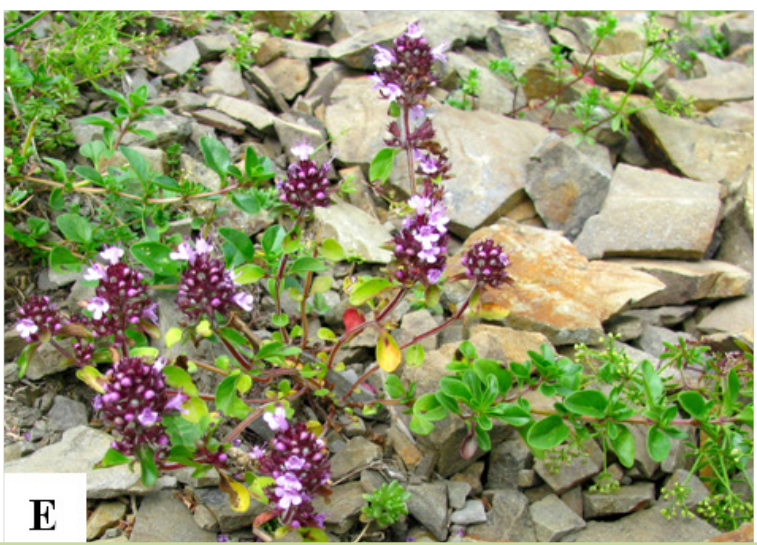

Figure 1 Plants of Thymus serpyllum (A), Th. pannonicus (B), Th. pulegioides (C), Th. $\times$ porcii (D), Th. alpestris (E) used in our study. Photos by Viktor Nachychko

\section{Preparation of plant extracts}

Freshly collected leaves were washed, weighted, crushed, and homogenized in $0.1 \mathrm{M}$ phosphate buffer (pH 7.4) (in proportion $1: 19, \mathrm{w} / \mathrm{w}$ ) at room temperature. The extracts were then filtered and used for analysis. All extracts were stored at $-20{ }^{\circ} \mathrm{C}$ until use. 


\section{Experimental fish}

Clinically healthy rainbow trout with a mean body mass of 80-120 g were used in the experiments. The experiments were performed in water at $14.5 \pm 0.5{ }^{\circ} \mathrm{C}$ and $\mathrm{pH} 7.2-7.4$. The dissolved oxygen level was about 9 ppm with additional oxygen supply, with a water flow of $25 \mathrm{~L}_{\mathrm{min}} \mathrm{m}^{-1}$, and a photoperiod of $12 \mathrm{~h}$ per day. The same experimental conditions were used during the whole research. The water parameters were maintained under constant surveillance. The fish were held in square tanks (150 fish per tank) and fed commercial pelleted diet.

\section{Muscle tissue samples}

The muscle tissue samples were homogenized in ice-cold buffer (100 mM Tris- $\mathrm{HCl}, \mathrm{pH} 7.2$ ) using a glass homogenizer immersed in an ice water bath. Homogenates were centrifuged at $3000 \mathrm{~g}$ for $15 \mathrm{~min}$ at $4{ }^{\circ} \mathrm{C}$. After centrifugation, the supernatant was collected and frozen at $-20{ }^{\circ} \mathrm{C}$ until analyzed. All enzymatic assays were carried out at $22 \pm 0.5^{\circ} \mathrm{C}$ using a Specol 11 spectrophotometer (Carl Zeiss Jena, Germany) in duplicate. The reactions were started by adding the tissue supernatant.

\section{Experimental design}

The supernatant of the muscle tissue was used to incubate with extracts of various species of Thymus (in a ratio 19:1) at room temperature. The control group (trout muscle tissue) was incubated with $100 \mathrm{mM}$ Tris-HCl buffer (pH 7.2) (in a ratio 19:1). The incubation time was 2 hours. Total antioxidant capacity was studied in the incubated homogenate (control group and in samples with extracts of various Thymus species).

\section{Measurement of total antioxidant capacity (TAC)}

The TAC level in the sample was estimated by measuring the 2-thiobarbituric acid reactive substances (TBARS) level after Tween 80 oxidation. This level was determined spectrophotometrically at $532 \mathrm{~nm}$ (Galaktionova et al., 1998). Sample inhibits the $\mathrm{Fe}^{2+} /$ ascorbate-induced oxidation of Tween 80 , resulting in a decrease in the TBARS level. Briefly, $0.1 \mathrm{~mL}$ of sample was added to $2 \mathrm{~mL}$ of $1 \%$ Tween 80 reagent, $0.2 \mathrm{~mL}$ of $1 \mathrm{mM} \mathrm{FeSO}_{4}$, and $0.2 \mathrm{~mL}$ of $10 \mathrm{mM}$ ascorbic acid. In the blank assay, $0.1 \mathrm{~mL}$ of distilled water was used instead of the sample. The mixture was heated in a water bath for $48 \mathrm{hrs}$ at $37^{\circ} \mathrm{C}$. After cooling, $1 \mathrm{~mL}$ of $20 \%$ trichloroacetic acid was added. The mixture was centrifuged at $3000 \mathrm{~g}$ for $10 \mathrm{~min}$. After centrifugation, $2 \mathrm{~mL}$ of supernatant and $2 \mathrm{~mL}$ of $0.25 \% 2$-thiobarbituric acid were mixed. The mixture was heated in a water bath at $95{ }^{\circ} \mathrm{C}$ for $15 \mathrm{~min}$. The absorbance of the obtained solution was measured at $532 \mathrm{~nm}$. The absorbance of the blank was defined as $100 \%$. The level of TAC in the sample (\%) was calculated with respect to the absorbance of the blank sample.

\section{Statistical analysis}

The mean \pm S.E.M. values were calculated for each group to determine the significance of the intergroup difference. All variables were tested for normal distribution using the Kolmogorov-Smirnov and Lilliefors test $(p>0.05)$. The significance of differences between the 
total antioxidant capacity level (significance level, $p<0.05$ ) was examined using the MannWhitney $U$ test (Zar, 1999). All statistical calculation was performed on separate data from each individual with Statistica 8.0 software (StatSoft, Krakow, Poland).

\section{Results and discussion}

In the present study, we investigated the influence of leaf extracts obtained from various Thymus representatives on the total antioxidant capacity in the muscle tissue of rainbow trout after incubation with extracts under in vitro conditions. The most potent antioxidant effect was demonstrated for the extracts of Th. alpestris, Th. $\times$ porcii, Th. pannonicus, Th. serpyllum, and Th. pulegioides compared to phosphate buffer control $(59.5,48,45.9,43.9$, and 38.8\%, $p<0.05$, respectively). The results showed that the leaf extract of Th. alpestris efficiently increased the TAC level in muscle tissue (Figure 2).

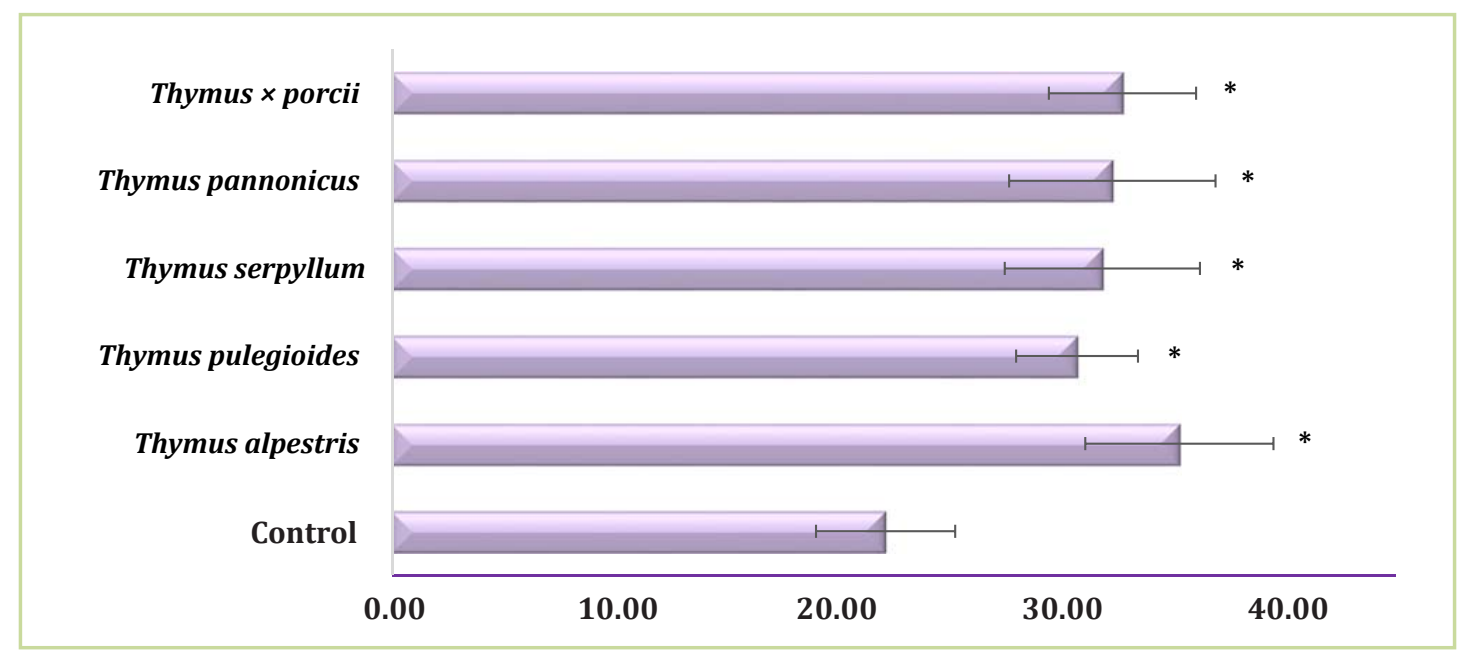

Figure 2 The total antioxidant capacity in the muscle tissue of rainbow trout after in vitro incubation with leaf extracts obtained from various Thymus representatives ( $\pm \mathrm{m}, n=8)$

* the changes are statistically significant $(p<0.05)$ compared to the control group

Treatment of muscle tissue by leaf extracts obtained from various Thymus representatives caused an increase of total antioxidant capacity in muscle tissue of trout. Therefore, it would be reasonable to suggest that this enhancement of antioxidant effects is determined by their by-products. There are different chemotypes, depending on the dominant component of the essential oil such as thymol, carvacrol, linalool, geraniol, thujanol, $\alpha$-terpineol, borneol, and $p$-cymene (Nabavi et al., 2015). High antioxidant activities have been reported for the thymol and carvacrol present in the Thymus plant. Thymol, carvacrol, $\gamma$-terpinene, and $p$-cymene are the major compounds of genus Thymus plants which are responsible for its biological and pharmacological properties such as anti-mutagenic, antitumor, antioxidant, antiinflammatory, etc. (Bhalla et al., 2013). In addition, results from in vitro and in vivo studies show that carvacrol possess a variety of biological and pharmacological properties including antioxidant, antibacterial, antifungal, anticancer, antimutagenic, antigenotoxic, analgesic, 
antispasmodic, anti-inflammatory, angiogenic, anti-parasitic, antiplatelet, spasmolytic, and vasorelaxant, insecticidal, antihepatotoxic and hepatoprotective activities and uses such as feed additive, in honeybee breeding and in gastrointestinal ailments (Baser, 2008). In recent years, considerable research has been undertaken in an effort to establish the biological actions of carvacrol for its potential use in clinical applications (Suntres et al., 2015). Areas for future research are also covered are inhibitions of microbial and fungal toxin production and the anti-inflammatory, analgesic, anti-arthritic, anti-allergic, anti-carcinogenic, anti-diabetic, cardioprotective, gastroprotective, hepatoprotective, and neuroprotective properties of carvacrol as well as metabolic, synergistic, and mechanistic aspects (Friedman, 2014).

Phenolic compounds act as free radical acceptors and chain breakers. They interfere with the oxidation of lipids and other molecules by rapid donation of a hydrogen atom to radicals. As an alternative antioxidant property, some phenolic compounds with dihydroxy groups can conjugate transition metals, preventing metal-induced free radical formation. The redox active metal ions such as $\mathrm{Cu}^{+}$or $\mathrm{Fe}^{2+}$ interact with hydrogen peroxide $\left(\mathrm{H}_{2} \mathrm{O}_{2}\right)$ through Fenton reaction to form hydroxyl radicals $(\cdot \mathrm{OH})$, which is the most reactive ROS known, being able to initiate free radical chain reactions by abstracting hydrogen from almost any molecule. Phenolic compounds with catecholate and gallate groups can inhibit metal-induced oxygen radical formation either by coordination with $\mathrm{Fe}^{2+}$ and enhance autoxidation of $\mathrm{Fe}^{2+}$, or the formation of an inactive complex with $\mathrm{Cu}^{2+}, \mathrm{Fe}^{2+}$, or $\mathrm{Cu}^{+}$with relatively weaker interaction. These two antioxidant actions can cause a reduction of the steady-state concentrations of free radicals and oxidant species. As a result, the subsequent oxidation of target molecules such as lipids, proteins, and nucleic acids is diminished (Dai and Mumper, 2010).

Pronounced antioxidant and free radical scavenging activity of the various Thymus species in vitro and in vivo was demonstrated in many studies. Mihailovic-Stanojevic et al. (2013) have indicated that aqueous extract obtained from Th. serpyllum (wild thyme) may protect against hypertension in an experimental model of essential hypertension. They have evaluated total phenol and flavonoid contents, antioxidant capacity, free radical scavenging activity and potential antihypertensive effect of aqueous extract obtained from Th. serpyllum in spontaneously hypertensive rats and in normotensive Wistar rats. Total phenol content of Th. serpyllum was $2008.33 \pm 10.6 \mathrm{mg}$. $\mathrm{L}^{-1}$ of gallic acid equivalents (GAE), and rosmarinic and caffeic acids were predominant phenolic compounds. The ferric reducing/antioxidant power and antioxidant capacity analysis revealed strong antioxidative properties of Th. serpyllum. In vitro nitric oxide-scavenging activity of $1 \mathrm{mg} . \mathrm{L}^{-1} \mathrm{Th}$. serpyllum extract was $63.43 \%$ with the $\mathrm{IC}_{50}$ value of $122.36 \mu \mathrm{g} . \mathrm{mL}^{-1}$. Bolus injection of Th. serpyllum extract $\left(100 \mathrm{mg} . \mathrm{kg}^{-1}\right.$ body weight i.v.) induced significant decrease of systolic and diastolic blood pressure and total peripheral resistance in spontaneously hypertensive rats, without effects on these parameters in normotensive Wistar rats. The cardiac index remained unchanged after Th. serpyllum extract treatment in all experimental rats. Given a dose of Th. serpyllum did not show significant nitric oxide-scavenging activity in vivo (Mihailovic-Stanojevic et al., 2013).

Chemopreventive efficacy of the Th. longicaulis C. Presl. extracts, by means of their antiinflammatory, cytotoxic and antioxidant activities were assessed in a study of Galasso et al. (2014). To this purpose, each extract underwent an extensive screening towards five human 
cell lines: CCRF-CEM (leukemia); U251 (glioblastoma); MDA-MB-231 (breast cancer); HCT116 (colon cancer) and MRC-5 (lung fibroblasts) through XTT [2,3bis(2-methoxy-4-nitro-5sulfophenyl)-5-[(phenylamino)carbonyl]-2H tetrazolium hydroxide] test. The ability of the extracts to counteract cyclooxygenase-2 (COX-2) expression was also evaluated by COX-2 expression assay in human THP-1 monocyte-derived macrophages. COX-2 inhibition could represent a valuable anticancer strategy as it is associated with carcinogenesis and overexpressed in a variety of human malignancies. Th. longicaulis extract sampled in the autumn season, which was particularly rich in rosmarinic acid and methylapigenin, exhibited a strong antioxidant and anti-inflammatory effectiveness (Galasso et al., 2014).

Natural antioxidants such as phenolic compounds, flavonoids, and other phytochemicals can act as free radical scavengers (Tohidi et al., 2017). They also delay the lipid oxidation process and might be valuable antibacterial and antioxidant natural sources and seem to be applicable in both medicine and food industry (Baharfar et al., 2015). In a study by Baharfar et al. (2015), flavonoid-, polyphenol- and anthocyanin-rich extracts of Th. kotschyanus Boiss. \& Hohen. aerial parts were evaluated for their antioxidant capacity, phenolic and flavonoid contents, and antibacterial activity. The results indicated that all of the samples possess high potent free radical scavenging and antioxidant activity. They were also rich in phenolic and flavonoid compounds. Interestingly, the antioxidant activity of various extracts positively correlated with their phenolic and flavonoid contents. Water extract which had the highest phenolic and flavonoid content, showed an appreciable 2,2-diphenyl-1-picrylhydrazyl (DPPH) radical scavenging activity as well as reducing power as compared with other extracts. On the basis of the obtained results from the antibacterial test, the extracts contained moderate to good growth inhibitory effect against both Gram-negative and Gram-positive bacteria. Therefore, the tested Thymus extracts might be valuable antibacterial and antioxidant natural sources and seem to be applicable in both medicine and food industry (Baharfar et al., 2015). Saidi et al. (2016) have investigated the antibacterial activity of Th. daenensis Čelak. extract against extended-spectrum $\beta$-lactamases (ESBL), metallo- $\beta$-lactamase-producing Gramnegative bacteria and methicillin-resistant Staphylococcus aureus (MRSA). Subsequently, the antioxidant activity of Th. daenensis extract was assessed. The association between phenolic compound and antioxidant activity was found for the ABTS $\bullet+$ method $(43.52 \%)$ in the lowest level, while, for FRAD and DPPH• methods other trends occurred $(70.5 \%$ correlation for DPPH• and 50.9\% for FRAD) (Saidi et al., 2016).

\section{Conclusions}

According to the results of this study, we addressed the hypothesis that by-products in the leaf extracts obtained from various Thymus representatives may be a major contributor to increase of the antioxidant capacity of muscle tissue of rainbow trout after incubation in vitro. To prove this hypothesis, separation and characterization of secondary metabolites compound in plant extracts are required for further study. Moreover, it should be noted that measurement only TAC can provide limited information about the antioxidant status because TAC assays do not measure all antioxidant components (Rubio et al., 2016). Special attention should be given to the evaluation of the effects of plant extracts/products on fish growth, 
hematological profiles, immune responses and resistance to infectious diseases (Bulfon et al., 2015). The present results suggest that the future herbal supplementation feeds responsible for returning antioxidant capacity of various tissue and, therefore, the triggering the immune system of the specific and innate immunity of salmonids. However, the exact mechanisms of inducing the biochemical and immunological parameter recoveries using modern molecular techniques should be applied to ensure that the species of herbal supplementation feeds used in aquaculture are correctly identified, for quality assurance as well as safety.

In conclusion, the obtained data provide a new perspective on the use of various Thymus species as a medicinal plant to improve the antioxidant response of rainbow trout. Further studies including the use of other medicinal plants as food additives in aquaculture, the assessment of its antioxidant effects on various tissues are in progress.

\section{References}

BAHARFAR, R., AZIMI, R., MOHSENI, M 2015. Antioxidant and antibacterial activity of flavonoid-, polyphenol-and anthocyanin-rich extracts from Thymus kotschyanus Boiss \& Hohen aerial parts. InJ. Food Sci. Technol., vol. 52(10), p. 6777-6783. http://dx.doi.org/DOI: 10.1007/s13197-015-1752-0

BARTOLUCCI, F., PERUZZI, L., PASSALACQUA, N. 2013. Typification of names and taxonomic notes within the genus Thymus L. (Lamiaceae). In Taxon, vol. 62(6), p. 1308-1314. http://dx.doi.org/ DOI: $10.12705 / 626.1$

BASER, K.H. 2008. Biological and pharmacological activities of carvacrol and carvacrol bearing essential oils. In Curr. Pharm. Des., vol. 14(29),: p. 3106-3119. http://dx.doi.org/DOI: 10.2174/138161208786404227

BHALLA, Y., GUPTA, V.K., JAITAK, V. 2013. Anticancer activity of essential oils: a review. In J. Sci. Food Agric., vol. 93(15), p. 3643-3653. http://dx.doi.org/DOI: 10.1002/jsfa.6267

BULFON, C., VOLPATTI, D., GALEOTTI, M. 2015. Current research on the use of plant-derived products in farmed fish. In Aquaculture Research, vol. 46(3), p. 513-551. http://dx.doi.org/DOI: 10.1111/ are.12238

CHANG, J. 2000. Medicinal herbs: drugs or dietary supplements? In Biochem. Pharmacol., vol. 59(3), p. 211-219. http://dx.doi.org/DOI: 10.1016/S0006-2952(99)00243-9

CITARASU, T. 2010. Herbal biomedicines: a new opportunity for aquaculture industry. In Aquac. Int., vol. 18, p. 403-414. http://dx.doi.org/DOI: 10.1007/s10499-009-9253-7

COSTA, P., GONÇAlVES, S., VALENTÃO, P., ANDRADE, P.B., COElHO, N., ROMANO, A. 2012. Thymus lotocephalus wild plants and in vitro cultures produce different profiles of phenolic compounds with antioxidant activity. In Food Chem., vol. 135(3),: p. 1253-1260. http://dx.doi.org/DOI: 10.1016/j.foodchem.2012.05.072

DAI, J., MUMPER, R.J. 2010. Plant phenolics: extraction, analysis and their antioxidant and anticancer properties. In Molecules, vol. 15(10), p. 7313-7352. http://dx.doi.org/DOI: 10.3390/ molecules15107313

FIGUEIREDO, A.C., BARROSO, J.G., PEDRO, L.G., SALGUEIRO, L., MIGUEL, M.G., FALEIRO, M.L. 2008. Portuguese Thymbra and Thymus species volatiles: chemical composition and biological activities. In Curr. Pharm. Des., vol. 14(29), 3120-3140. http://dx.doi.org/DOI: 10.2174/138161208786404218.

FRIEDMAN, M. 2014. Chemistry and multibeneficial bioactivities of carvacrol (4-isopropyl-2methylphenol), a component of essential oils produced by aromatic plants and spices. In J. Agric. Food Chem., vol. 62(31), p. 7652-7670. http://dx.doi.org/DOI: 10.1021/jf5023862 
GALAKTIONOVA, L.P., MOLCHANOV, A.V., EL'CHANINOVA, S.A., VARSHAVSKIII, BLA. 1998. Sostoyanie perekisnogo okisleniya lipidov u bolnyih s yazvennoy boleznyu zheludka i dvenadtsatiperstnoy kishki [Lipid peroxidation in patients with gastric and duodenal ulcers]. In Klinicheskaia Labaratornaia Diagnostika, vol. 6, p. 10-14 (In Russian).

GALASSO, S., PACIFICO, S., KRETSCHMER, N., PAN, S.P., MARCIANO, S., PICCOLELlA, S., MONACO, P., BAUER, R. 2014. Influence of seasonal variation on Thymus longicaulis C. Presl. chemical composition and its antioxidant and anti-inflammatory properties. In Phytochemistry, vol. 107, p. 80-90. http://dx.doi.org/DOI: 10.1016/j.phytochem.2014.08.015

GALINA, J., YIN, G., ARDÓ, L., JENEY, Z. 2009. The use of immunostimulating herbs in fish. An overview of research. In Fish Physiol. Biochem., vol. 35(4), p. 669-676. http://dx.doi.org/DOI: 10.1007/ s10695-009-9304-z

HARIKRISHNAN, R., BALASUNDARAM, C., HEO, M.-S. 2011. Impact of plant products on innate and adaptive immune system of cultured finfish and shellfish. In Aquaculture, vol. 317, p. 1-15. http://dx.doi.org/DOI: 10.1016/j.aquaculture.2011.03.039

KHAN, I.A., ABOURASHED, E.A. 2010. Leung's Encyclopedia of Common Natural Ingredients Used in Food, Drugs, and Cosmetics. $3^{\text {rd }}$ ed., John Wiley and Sons, Inc., Hoboken, NJ, pp. 594-597.

KOSTAKI, M., GIATRAKOU, V., SAVVAIDIS, I.N., KONTOMINAS, M.G. 2009. Combined effect of MAP and thyme essential oil on the microbiological, chemical and sensory attributes of organically aquacultured sea bass (Dicentrarchus labrax) fillets. In Food Microbiol., vol. 26, p. 475-482. http:// dx.doi.org/10.1016/j.fm.2009.02.008

KUKLINA, A., SOROKOPUDOV, V., STEPANOVA, A. 2017. Amelanchier Medik. (Rosaceae) Fruits A Nutrition Dietary Product And A Source Material For Phytopharmacology. In Agrobiodiversity for Improving Nutrition, Health and Life Quality, vol. 1, p. 268-272. http://dx.doi.org/DOI: 10.15414/ agrobiodiversity.2017.ISSN-ISSN.268-272.

KULEVANOVA, S., KAFTANDZIEVA, A., DIMITROVSKA, A., STEFKOV, G., GRDANOSKA, T., PANOVSKI, N. 2000. Investigation of antimicrobial activity of essential oils of several Macedonian Thymus $\mathrm{L}$. species (Lamiaceae). In Boll. Chim. Farm., vol. 139(6), p. 276-280.

MIHAILOVIC-STANOJEVIC, N., BELŠČAK-CVITANOVIĆ, A., GRUJIĆ-MILANOVIĆ, J., IVANOV, M., JOVOVIĆ, DJ., BUGARSKI, D., MILORADOVIĆ, Z. 2013. The antioxidant and antihypertensive activity of extract from Thymus serpyllum L. in experimental hypertension. In Plant Foods Hum. Nutr., vol. 68(3), p. 235-240. http://dx.doi.org/DOI: 10.1007/s11130-013-0368-7

MORALES, R. 2002. The history, botany, and taxonomy of the genus Thymus. In: Stahl-Biskup E., Sáez F. (Eds.) Thyme. The genus Thymus. Taylor \& Francis, London, New York, pp. 1-43.

NABAVI, S.M., MARCHESE, A., IZADI, M., CURTI, V., DAGLIA, M., NABAVI, S.F. 2015. Plants belonging to the genus Thymus as antibacterial agents: from farm to pharmacy. In Food Chem., vol. 173, p. 339-347. http://dx.doi.org/DOI: 10.1016/j.foodchem.2014.10.042

NACHYCHKO, V. 2014. Rid Thymus L. (Labiatae Juss.) u flori Ukrainskykh Karpat: systematyka i taksonomichni problemy [The genus Thymus L. (Labiatae Juss.) in the Ukrainian Carpathians' flora: systematics and taxonomic problems]. In Visnyk of Lviv University. Biological Series, vol. 64, p. 159-169 (In Ukrainian).

NACHYCHKO, V.O. 2015. Diahnostychni oznaky predstavnykiv Thymus sect. serpyllum i T. sect. marginati (Lamiaceae) ta rekomendatsii shchodo yikhnoi herbaryzatsii [Diagnostic features of representatives of Thymus sect. serpyllum and Th. sect. marginati (Lamiaceae) and guidance for their herborization]. In Visnyk Kharkivskoho natsionalnoho universytetu imeni V.N.Karazina. Ser. biol., vol. 25, p. 77-89. (In Ukrainian).

NACHYCHKO, V.O., HONCHARENKO, V.I. 2016. Hibrydy rodu Thymus L. (Lamiaceae) u flori zakhidnykh rehioniv Ukrainy: taksonomichnyi sklad i poshyrennia [Hybrids of Thymus L. (Lamiaceae) genus 
in flora of the western regions of Ukraine: taxonomic composition and distribution]. In Biolohichni Studii, vol. 10(1), p. 163-186. (In Ukrainian). http://dx.doi.org/10.30970/sbi.1001.442

RUBIO, C.P., HERNANDEZ-RUIZ, J., MARTINEZ-SUBIELA, S., TVARIJONAVICIUTE, A., CERON, J.J. 2016. Spectrophotometric assays for total antioxidant capacity (TAC) in dog serum: an update. In $B M C$ Veterinary Research, vol. 12, p. 166. http://dx.doi.org/DOI: 10.1186/s12917-016-0792-7

SAIDI, M., SADEGHIFARD, N., KAZEMIAN, H., SEKAWI, Z., BADAKHSH, B., FRIADIAN, S., GHAFOURIAN, S. 2016. Ex Vivo Evaluation of Thymus daenensis as an Antioxidant and Antibacterial Medicinal Herb. In Drug Res. (Stuttg.), vol. 66(12), p. 657-659. http://dx.doi.org/DOI: 10.1055/s-0042-113457

SÖNMEZ, A.Y. BILEN, S., ALAK, G., HISAR, O., YANIK, T., BISWAS, G. 2015. Growth performance and antioxidant enzyme activities in rainbow trout (Oncorhynchus mykiss) juveniles fed diets supplemented with sage, mint and thyme oils. In Fish Physiol. Biochem., vol. 41(1), p. 165-175. http://dx.doi.org/10.1007/s10695-014-0014-9

SUNTRES, Z.E., COCCIMIGLIO, J., ALIPOUR, M. 2015. The bioactivity and toxicological actions of carvacrol. In Crit. Rev. Food Sci. Nutr., vol. 55(3), p. 304-318. http://dx.doi.org/DOI: 10.1080/10408398.2011.653458

TOHIDI, B., RAHIMMALEK, M., ARZANI, A. 2017. Essential oil composition, total phenolic, flavonoid contents, and antioxidant activity of Thymus species collected from different regions of Iran. In Food Chem., vol. 220, p. 153-161. http://dx.doi.org/DOI: 10.1016/j.foodchem.2016.09.203

VERGUN, O., BRINDZA, J., RAKHMETOV, D. 2017. Total Antioxidant Activity Of Plants Of Symphytum L. Species. In Agrobiodiversity for Improving Nutrition, Health and Life Quality, vol. 1, p. 488-492. http://dx.doi.org/DOI: 10.15414/agrobiodiversity.2017.2585-8246.488-492

VIUDA-MARTOS, M., RUIZ-NAVAJAS, Y., FERNÁNDEZ-LÓPEZ, J., PÉREZ-ÁLVAREZ, J.A. 2011. Spices as functional foods. In Critical Review in Food Science and Nutrition, vol. 51(1), p. 13-28. http://dx.doi. org/DOI: 10.1080/10408390903044271

YASIN, N.M.N., ABOU-TALEB, M. 2007. Antioxidant and antimicrobial effects of marjoram and thyme in coated refrigerated semi-fried mullet fish fillets. In World J. Dairy Food Sci., vol. 2, p. 01-09.

ZAR, J.H. 1999. Biostatistical Analysis. $4^{\text {th }}$ ed., Prentice-Hall Inc., Englewood Cliffs, New Jersey. 